\title{
Solution to highest melting point challenge
}

\author{
John Arblaster ${ }^{1}$
}

(C) Springer-Verlag Berlin Heidelberg 2015

The winner of the highest melting point challenge (published in volume 407 issue 12) is:

William E. Acree, Jr., Dept. of Chemistry, University of North Texas, Denton, TX, USA

The award entitles the winner to select a Springer book of his choice up to a value of $€ 100$.

Our Congratulations!

\section{Solution}

The phrase " $\mathrm{HfTa}_{4} \mathrm{C}_{5}$ has the highest melting point of any known material: $4215{ }^{\circ} \mathrm{C}$ " has become ingrained in textbooks, yet it is faulty because of a simple unitconversion error.

In 1930 Agte and Alterthum determined the melting point of a mixed carbide $4 \mathrm{TaC}+1 \mathrm{HfC}$ compound to be " 4215 in "abs", which is $4215 \mathrm{~K}$ [1]. Because of a confusion in reporting units this was reported as $4215^{\circ} \mathrm{C}$, and this value proliferates throughout the literature to this day. The original value in degrees Celsius is, of course, $3942{ }^{\circ} \mathrm{C}$; but this value must be treated with some reservation because of the difficult experimental problems when dealing with this most refractory substance, which were not overcome until the 1960s in the laboratories at the Aerojet General Corporation in California.

This article is the solution to the Analytical Challenge to be found at http://dx.doi.org/10.1007/s00216-015-8564-y

John Arblaster

jwarblaster@yahoo.co.uk

1 Wombourne, West Midlands, UK
In the 1960s it was established that the melting points of the tantalum and hafnium carbides were not highest for stoichiometric composition, i.e. $\mathrm{TaC}_{1.00}$ and $\mathrm{HfC}_{1.00}$. In fact, nonstoichiometric tantalum carbide at $\mathrm{TaC}_{0.88}$ had a melting point of $3983 \pm 15^{\circ} \mathrm{C}[2]$ and hafnium carbide at $\mathrm{HfC}_{0.94}$ had a melting point determined as $3928 \pm 20^{\circ} \mathrm{C}$ [3], which was later corrected to $3950 \pm 20^{\circ} \mathrm{C}$ [4] to account for zirconium impurities in the original hafnium used to prepare the carbides.

Rudy [5] revealed that $\mathrm{TaC}_{0.88}$ and $\mathrm{HfC}_{0.94}$ were completely soluble in each other, and formed intermediate melting points trending linearly from the one pure compound to the other from $3928^{\circ} \mathrm{C}$ to $3983{ }^{\circ} \mathrm{C}$ with no higher melting point for mixed carbides, in contradiction to Agte and Alterthum. Values of $4050{ }^{\circ} \mathrm{C}$ determined by Samsonov and Paderno [6] and $3990^{\circ} \mathrm{C}$ by Andrievskii et al. [7] may also have anticipated a peak at $4 \mathrm{TaC}+1 \mathrm{HfC}$, but the quality of these measurements must be queried because of the extreme experimental difficulties which existed, meaning that incorrect temperature corrections may have been applied when converting observed temperatures to true temperatures.

It is clear that the current value given throughout the literature for this most refractory substance is incorrect, and ought to be corrected to nonstoichiometric tantalum carbide, $\mathrm{TaC}_{0.88}$, at $3983 \pm 20^{\circ} \mathrm{C}$.

\section{References}

1. Agte C, Alterthum H (1930) Z Tech Phys 11:182-191

2. Rudy E, Harmon DP (1965) United States Air Force Materials Laboratory Rept. AFML-TR-65-2, Part I, Vol. V

3. Rudy E (1965) United States Air Force Materials Laboratory Rept. AFML-TR-65-2, Part I, Vol. IV

4. Storms EK (1967) The refractory carbides. Academic Press, New York 
5. Rudy E (1965) United States Air Force Materials Laboratory Rept. AFML-TR-65-2, Part II, Vol. I

6. Samsonov GV, Paderno VN (1965) Izvestia Akademii Nauk SSSR Metally, Part 1, Pages 180-188 (Russian Metallurgy - Metally, Part 1, pp: 119-124)
7. Andrievskii RA, Strel'nikov NS, Poltoratskii NI, Kharkardin ED, Smirnov VS (1967) Poroshkovaya Metallurgiya. Part 1, Pages 85 to 88 (Powder Metallurgy and Metal Ceramics, Vol. 6, Part 1, pp: 65-67) 